\title{
LOGISTICAL OUTSOURCING AS AN EFFECTIVE ENTERPRISE ACTIVITY MECHANISM RISING
}

\author{
OlEG TKACH, LIUBOV HRYNIV, HALYNA MYKHAILIV
}

\begin{abstract}
The purpose of the article is to substantiate logistics outsourcing as an effective mechanism for improving the efficiency of the enterprise.

The authors summarize the arguments and counterarguments in the scientific discussion on logistics outsourcing as one of the best methods of optimizing resources in the activity of enterprises, one of the important factors of modern business. Systematization of the results of the research of scientific sources made it possible to identify the problems of outsourcing use in various spheres of activity of economic entities. Systematization of studies of aspects of enterprise management based on logistic approaches has allowed formulating the statement that special value all over the world in logistics is devoted to outsourcing. For many years there is a tendency in this area to transfer a part or all of the logistics functions to specialized companies and outsourcing of logistics services is used by the vast majority of enterprises. Because, as higher the level of consumption in the country, there is more need to involve in the supply chain the goods of qualified logistics operators and transfer part of their operations to logistics outsourcing.

The authors estimate the logistic outsourcing of the enterprise of PE "VEGA LTD" for the method of $\mathrm{Yu}$. Zhelinskiy, which combines the change of income and expenses of the enterprise. Based on the calculations, it is proved that outsourcing for PE "VEGA LTD" is profitable. Therefore, it is advisable to use outsourced services not only for transport logistics but also for other logistic activities of the enterprise.

In the process of investigating the problems of logistics outsourcing and its impact on the efficiency of foreign economic activity of the company, the authors proved that outsourcing in logistics is one of the most modern business models. The use of this approach makes it possible to achieve significant competitive advantages in the activity of the enterprise. The main motives that drive outsourcing of logistics functions are the desire to make the business manageable, reduce transaction costs while obtaining quality service and profit. The results of the study are of practical importance and may be useful to scholars interested in the study of logistical outsourcing, as well as to the enterprises where outsourcing is most commonly used.
\end{abstract}

Keywords: logistic outsourcing, types of outsourcing in logistics, logistics providers, operators, forms of cooperation of enterprises, logistics services.

JEL Classification: D24, E23, F15, M21, M31. 


\section{INTRODUCTION}

Competition aggravation and intensification in the different business processes, new information technologies development and its universal using in all types of life and business activity, transaction speeding up, life cycling obsolescence and abbreviation, consumers' demands and strictness rising have made the Companies look over their strategies of business acts. These challenges caused qualified firms attraction that some part of its own business functions including logistics were passed on.

Logistics outsourcing has taken a place in a practice of the many Companies independently from the scale and type of activity that had taken the attention of the researches.

Today, the logistics outsourcing market is being under development wave because the quantity of the new Companies have been founding and some percentage of them are looking for a qualified specialist which could logistics functions manage outside of the Company.

\section{THEORETICAL BACKGROUND}

The terms and conditions of logistics outsourcing were widely described in the Western scientists works such as P. Bagchi \& H. Virum, J. Langley [1], B. Sahay \& R. Mohan [2]. By these authors a content was opened and scientific-theoretic issues summarized for all types of logistics outsourcing implementation as an effective enterprise activity mechanism.

One of the popular resources optimization methods in the different activity spheres and basic business providing factors is outsourcing.

The problems of outsourcing implementation providing in different types of Enterprise activity were researched by number of local scientists, it was described in the works of the next scientists as M. Dovba [3], V. Krasnoshapka \& I. Trohumets [4], O. Tryfonova \& N. Trushkina [5].

Outsourcing in logistics has special means all over the world. In this sphere a tendency has been monitored of partial or all the logistics functions transfer to specialized companies and outsourcing of logistics services is used by the enterprise majority.

As high demand in a country, a need arises for goods network organizing involve of qualified logistics operators and transfer to one of the operation parts for logistics outsourcing.

The researches of enterprise management on a base of logistics in Ukraine were concluded by the next scientists: T. Glushenko [6], V. Krasnoshapka \& I. Trohumets [4], K. Zavgorodniy [7].

Notwithstanding the number of scientific work concerns about logistics and outsourcing cohesion in the aspect of enhancement of enterprise competition rising and expenses decline in present, innovative development model searching still is actual and one of this model presumes an implementation of logistics outsourcing in enterprise management.

A. Pasichnyk [8], K. Bilovskyi [9], L. Hrytsyna [10], O. Tryfonova \& N. Trushkina [5] were involved in the research of transport logistics, logistics outsourcing and its development in the transportation system, a transfer of logistics functions to outsourcing with a term of enterprise management optimization.

Transportation, storage and assembling are the main points that have been transferred to logistics outsourcing in Ukraine. These three logistics activity spheres make $85 \%$ of profit to logistics operators.

L. Hryniv [11] states that logistics is a key factor in enterprise management improvement, the transportation flows as a local and international, including Ukrainian transit potential.

H. Mykhailiv [12] researched outsourcing implementation by the local Ukrainian enterprises like a new type of cooperation that will permits to provide economic activity more effective, to release additional resources and direct it for enterprise development and to strengthen the market competition positions.

O. Tkach researched outsourcing as a modern method of different economic subjects cooperation that permits obtaining the mutually beneficial results within a short period and a long period of time. 


\section{Research Objective, Methodology and Data}

The article matter - motivating factors research, outsourcing advantages and disadvantages implementation in Enterprise logistics, and managing decisions using the improving concern of logistics functions passed to outsourcing on.

The research object is logistics activity of Vega Ltd. logistics system.

The subject research is logistics outsourcing as an effective Enterprise activity rising.

In this article, the research had been concluded concern with management decisions effectiveness justification of logistical outsourcing implementation. In the process of logistics outsourcing expediency researches the methods of scientific knowledge of phenomena and processes in economic activity, such as comparative analysis. Within local and foreign scientists work summarizing, historical method (for logical outsourcing means specification and with a purpose for driving forces and problems with logical servicing raising in a modern enterprise activity; formal-logical method and summarizing method (by the types of logistics providers definition and definition of cooperation by PL-provider with a range of services); analyze and synthesis (within the estimation of possible risks from taken decisions concern to outsourcing using); induction and deduction (within a typical model of definition concern implementation of managing decision about logistics outsourcing possibility using by foreign trade activity).

\section{RESUlTS AND DisCUSSION}

In the modern changeable, dynamic, compatible terms of the external environment, there are many of the Companies are looking for ways of improving all of the activity spheres. This also concerns its logistics. The basic point of enterprise activity is a delivery network management of the products and information current guarantee along with the whole enterprise delivery network. Thus, they are more concentrated and specialized with a help of outsourcing activity, which is far away from its basic business.

For a bigger number of enterprises, logistics is not a major business competence but logistics needs a lot of resources and attention due to keep the logistics Department (Dpt.) functioning. Use to be an own logistics Dpt. - does not mean a high level of logistics servicing and low level of logistics expenses. In addition, hired managers demand wages constantly raising up that do not confirm desired results and manager competencies. As a result, sometimes more profitable is to pass logistics outsourcing out.

Outsourcing in logistics activity means passing this activity out to a third provider, as a logistics servicing supplier. As an outsourcer can be a separate enterprise or several Companies, thanks to them, it is possible to decline the expenses to logistics.

With time passing by some enterprises came to the conclusion that without the cooperation of the knowledgeable logistics specialists to improve the business process in this sphere is practically unreal. Once the logistics were developed by the enterprise has invested money into the workers, the warehouses, and so on, but with a time they came to the conclusion that logistics outsourcing is a more optimal way for expenses decline. Outsourcing of logistics activity makes effectiveness rising from $9 \%$ to $15 \%$ capacity and quality rising [13].

The enterprises in logistics use to take one of the two alternatives - either to provide logistics functions by them or pass it out. The number of enterprises does not pass logistics services out concern for some reason. They establish their own Dpt. It is usually happens in enterprises where for the owner is important to keep the logistics schemes as unique.

Due to define the mean of logistics outsourcing some samples had been invented in the literature. For example, Sink and Langley (1997) and Millen et al (1997) says, that logistics outsourcing is an external supplier using for conducting some or all logistics services of the firm which are provided by the firm. Those definitions are being kept by [14], which added that logistics outsourcing is getting more force tendency in the modern enterprise because of the number of priorities are brought by. In the 
presented research all different propulsions and problems have been estimated with a connection of logistics servicing rising.

Outsourcing is one of the successful business models which include passing non-basic functions enterprise out and all the connected activities to outsourcer management.

With the connection of several profiles of this point such as logistics outsourcing (outsourcing of logistics decision) is vied from the following theories:

1. Resources bound theory.

2. Network theory.

3. Transaction cost economy.

1. Resources bound theory (RBT).

RBT looks at the Company like resources totality which spread heterogeneous [5]. Hereby, the meaning of logistics is defined as management optimization by the material and related its information and financial flows. Term "resources" concerns not only material resources such as warehouses, equipment, and factories but also non-material actives such as knowledge, know-how and organizational activities. According to this theory, the Company needs to ensure the right type of resources effective flow from its surrounding with the purpose of survival on the market, competition rising and stability [4].

Logistics servicing transfer to outsourcing permits the Company to get access to a wide not owned resources spectrum, to the keep competition on the market, and to obtain access to additional resources. By the way, the fact of the additional resources access does not explain the reason fully why the Companies transfer their own logistics services to the suppliers of logistics that takes to Network Theory (NT).

2. Network Theory (NT).

The effectiveness of logistics activity is defined by component elements synergies effect of the right established logistics network, logistics system and also system cooperation. The theory NT stipulates that outsourcing permits the Company to manage the supply network as a whole through relations forming and network coordination. Thus, a need is occurred by the resources exchange between of the Companies [15]. This theory points out that thanks to system establishing, links creation, and cooperation between Companies, they can obtain necessary (and absent) resources. Attention concentrates on alliance forming between the Companies.

3. Transaction cost economy.

From the point of economy cost transaction theory, view the Companies logistics servicing transfer was based on a sum of transaction minimization and production expenses. This theory is based on a point that supplier logistics servicing outsourcing is to be happened when there was a possibility to decline transactional expenses.

Stipulated principles are explained [8] and noticed that in a case of low transactional expenses the Company will face to outsourcer service, if these expenses will be high the Company will provide this activity by itself.

Hereby, this theory does not explain all the logistics processes and the connected decisions with it.

Basically, the reasons that make the functions transfer to outsourcing are the following:

- own resources absent;

- limitation expenses needs;

- basic types of activity concentrated necessity;

- competitive advantages in obtaining desire.

Necessary to recall the next two reasons:

a) Company management does not know how to act:

- there is not a future perspective of further development of a present activity direction;

- the Company is starting to lose its own market advantage;

b) Management of the Company is not able to formulate an exit from a current situation.

On a whole, outsourcing is effective by following terms: 
- is worked out process with a history of successful and profitable contracts;

- gives a chance to obtain improvements which are not achievable by any of the departments;

- improves a Company activity and defined process;

- proposes expenses surveillance which is not possible by internal Dpt. acts;

- unpredictable expenses limiting;

- servicing quality improvement;

- permits to be a competitiveness;

- gives a possibility to concentrate on the basic types of activity and the sources of profit;

- is an effective method of corporative culture changes;

- proposes not reachable by inner Dpt. quality level;

- foreseen a flexible attitude to workers quantity;

- gives an opportunity to improve their own knowledge.

Very often mean of "outsourcing" is used in the context of problem-solving "to produce" or "to buy" [16]. But today the mean of outsourcing coming out from its common means - as a method business providing when second types of Company activity are passed on to the external organization. This organization is able to use all given resources by the interests of the Company's customer.

The present experience testifies that outsourcing implementation has a reason in the following cases:

- need has occurred as for labor and material resources;

- activity of the Company in different directions is not connected with each other;

- job accomplishment requires to use experience and professional knowledge;

- company activity is undone survival of different market fluctuation that led to high expenses for stuff education;

- technology is changing so fast, that demands big investments.

In addition, outsourcing is considerable expenses control. Its realization ensures:

- more serious expenses transparency for business management and its process;

- service-provider involves the own stuff for the project's realization as necessary;

- cooperation of organization with service-provider ensures expenses decline which is used for infrastructure and tools etc.

The specialists use to separate some type of outsourcing as following:

- business-process outsourcing: foresees the delegation of the task that is not a concern to a main type of work for implementation by another Company;

- productive outsourcing: for an instant, new product creation with implementation by another Enterprise service;

- IT outsourcing;

- bookkeeping outsourcing;

- out staffing; submitting the stuff for a period to some separated tasks providing.

Commonly, outsourcing is used for entrepreneur's support and development. These are:

- scientific research and analytical work organization according to Company points;

- entrepreneurial education;

- infrastructure organization development program had been invented for small and medium business support;

- inventing practical manuals and training materials by special directions.

Due to the stipulated work algorithm, a Contract between Company - Customer and outsourcing Agency has been accomplished where the following information is mentioned:

1. Names, addresses of the Parties; terms of the Contract; description of the Customer acts are transferred to management by accepting Party.

2. Management manual, rights, and obligations are confirmed for each manager.

3. All types of characteristics are to be passed on to the responsibility of the Supplier according to the Contract including Dpt's are to be left in the client organization.

4. Contract terms for validation and termination. 
5. Negotiations terms concern the Contract prolongation.

6. Risks/profit distribution terms.

7. Problems solving terms which could arise under the acts of external (force majeure) acts, for instance, low change and the ways of influence toward Contract implementation.

8. All payments and compensations characteristics belong to the service supplier and Client.

Outsourcing is a new progressive activity management organization which that ensures the not related to basic production functions transfer to the specialized Companies with qualified staff (8).

Local Enterprises outsourcing implementation is:

- a new type of production which permits the Enterprises to provide economic activity more effectively, to release additional resources and direct it for Enterprise development and make the strongest competitive position on a market;

- the point of economic effectiveness outsourcing implementation improvement needs to be further developed including Ukrainian law system development in these directions and also the mechanism of outsourcing supplier reliability settlement.

Outsourcing is at the beginning level in Ukraine and gives a possibility to use it as a base for system management improving the number of the Enterprises which have not been providing a similar experience.

We think that logistics is more perspective sphere that is enriched by progressive and aimed to oriented professionals who are ready to adapt to new management instruments implementation and to risk with a matter of strategic targets achievement.

Outsourcing is a modern type of different economic subject cooperation that gives a possibility to obtain positive mutual results within a short time and long periods. In the developed countries and Ukraine so this cooperation has rising the chances and perspectives of high economic development. By this, is important to define for any of the Contract and terms outsourcing which means optimal type.

In Europe the value of logistics functions are transferred to outsourcing Companies such as $61 \%$ transportation service; 35\% - warehouses; $25 \%$ - information system; $15 \%$ - revers logistics; $13 \%$ - fleet management; $11 \%$ - costs minimization; $8 \%$ - supplier management; $6 \%$ - order scheduler sheets; $5 \%$ customers support.

The main obstacle for outsourcing development in Ukraine is the lowest state support, the impossibility for effective control for an outsourcing provider, and its economic status. One of a drawback is partnership relations which happened could be unreliable.

Also, the obstacle in the process of logistics outsourcing can be logistics infrastructure absence. Logistics infrastructure development gives to the Western Countries not only to ensure their own needs by transport - logistics servicing but also gives them to other Countries. Ukrainian transit potential is used only for $60 \%$. The income from the transit and coherent servicing complex is $6 \%$ GIP. Because ineffective use of Ukrainian potential occur that the Country did not receive $2.5 \mathrm{mln}$. usd. [11].

In addition, outsourcing progression state support is pretty important in modern economic conditions [1]. For example, India and Ireland are the world leaders in the outsourcing market thanks to State support and state structures of development. Despite the obstacles on the outsourcing development way in Ukraine, there are some advantages which support the outsourcing operations providing, thus low wages compare with Europe and the USA, a high unemployment rate of qualified staff; ability to communicate in foreign languages.

Outsourcing is an influential factor concern with Companies effective operations. It is the main element for expenses reduction. Also outsourcing influences concern to enterprise's competitive position.

Priorities and disadvantages of outsourcing are stipulated concern to economic activity [10].

The common advantage of logistics outsourcing includes the following points:

- risks clear distribution;

- business-process and ways of its effectiveness rising;

- expenses quantity shorting thanks to staff quantity reduction.

These are management advantages of logistics outsourcing: 
- management control improving capability;

- growing potential definition possibility and all the possible obstacles cancelation;

- perspective to locate attention and necessary resources on the main activity like a customer demands and company targets concern to the technical-technological advantages necessaries;

- high-level mission accomplishment access and necessary technology using;

- reliable servicing and quality rising.

Due to implement logistics outsourcing in Ukraine is necessary to avoid the obstacles that cause its unfavorable development.

These obstacles can be: uncertainty concern to Company secrets announcing by involved stuff, uncertainty concerns stuff professionally. Thus, the managers are not able to trust to other Companies do not take into consideration that these Companies thanks to narrow specialization are supported by the qualified staff which has been cooperating with many other Companies and implements their experience in the different spheres of activity.

In a case of an implemented decision by the Board of Directors is necessary to understand how will tide the Company up with the future Partner. It means what kind of cooperation the Company has been looking for: for hierarchical or market-oriented.

By hierarchical cooperation very tide interdependence is aroused, in practice it means cooperation between main and daughter Companies.

In the case of mutual work organized by the type of external partnership it's being qualified as a market-oriented.

Very important is the fact for what period these links are established: long term or short term or it can be made for once.

It is necessary to consider: as much number of the Enterprises are to be involved in cooperation [6]. Additionally, in the case of long-term cooperation to conceal the Contract is more difficult. It can be possible only in the case of big expenses costs.

Necessary to consider, the decision about outsourcing cooperation is big influence on enterprise structure. That is important to be prepared properly and estimate all advantages and risks properly.

In this cooperation, the Contract forms are very important because in case of nonfulfillment obligations the Parties will require losses compensation [17].

All expenses are aroused within some business-project conducting control could be estimated only approximately and this is a big drawback. The quality problems can be regulated basically by a number of acts implementing toward quality management for example logistics data.

Some instruments are to be involved for the expenses analyzing due to display the separate expenses for each provided decision and evaluate it.

Logistics providers - enterprises make logistics servicing complex. Different providers are different by technological level and servicing range [18].

The first level logistics includes internal logistics where all transportation, storage service, and other operations are to be concentrated inside of the organization - Customer. 1PL-providers are not logistics intermediary, because all functions are to be made by cargo owner (Fig. 1).

Second level logistics are external (2PL) and make ordinary servicing range which links to transportation and storage. 2PL-providers are logistics intermediaries.

For above mentioned could be transportation Companies; custom brokers; expeditors; custom warehouses; temporary storagy; agents; warehouses complexes and cargo terminals.

2PL providers have a narrow specialization but nevertheless, they have checked database and work experience in some spheres. Second level providers work on the local or regional markets.

Third level logistics (3PL) are external logistics that cooperates to all logistics services into one complex and includes additional services such as cargo storage, invention and design of different information systems with a helper using servicing.

3PL-provider is commonly called an intermediary which gives the logistics services complex to the customer. This type of Enterprises takes into own control some or all logistics functions. These logistics intermediaries commonly work within interregional areas on the bases of long terms Contracts. 
Fourth level logistics (4PL) cooperate by external and internal logistics. 4PL providers main difference from 3PL system attitude implementation toward all customer logistics process management. These logistics providers work on the world market in terms of strategic partnership.

Fifth logistics level (5PL) - internet logistics. 5PL provider submits the whole complex of the service for an account of world network using. This is a vertical partner: from one side he has all information about the network member's capabilities, from another - IT product which gives a possibility to create the optimal network inside of the logistics systems.

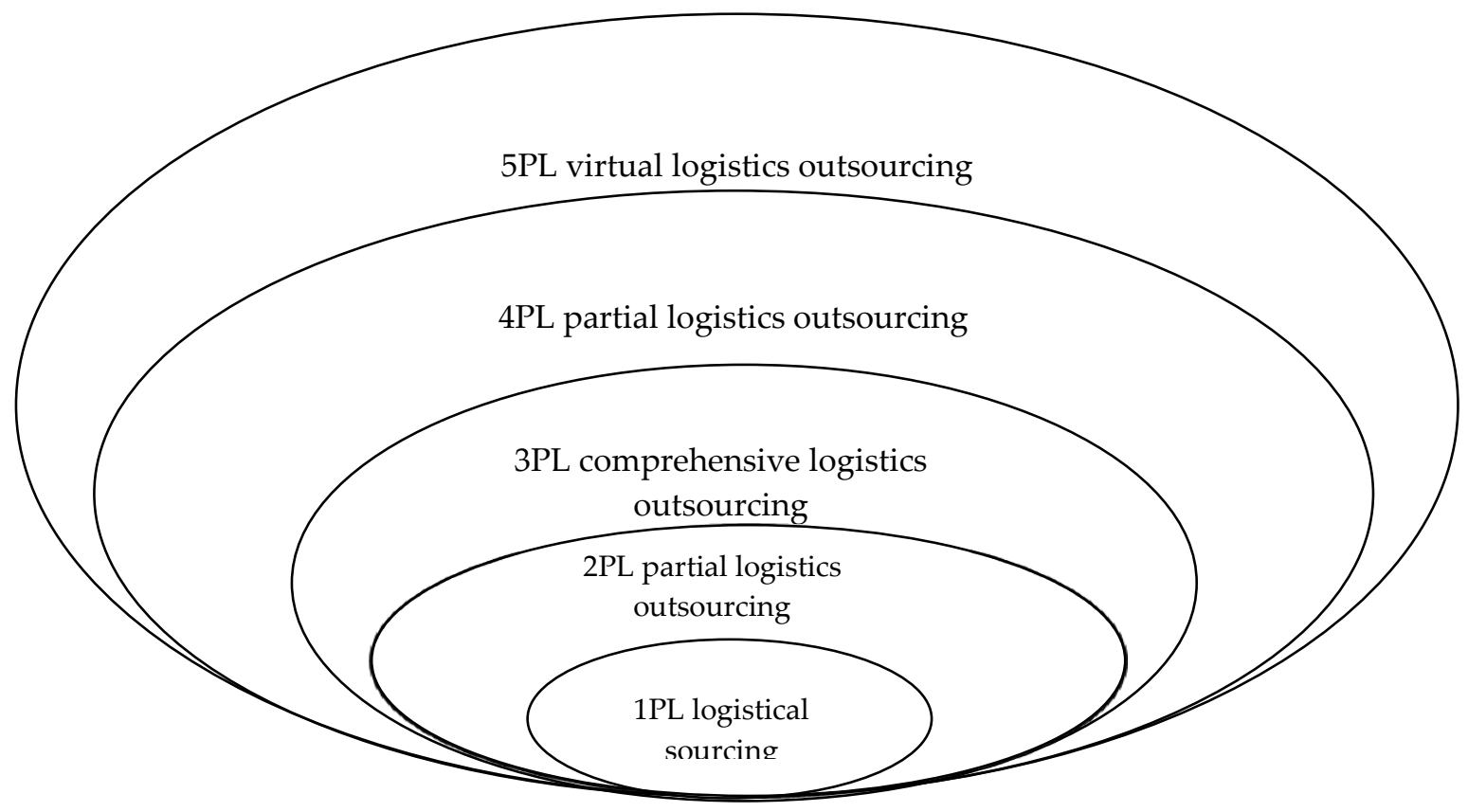

Fig. 1. Interconnection of the PL-providers with services range. Source: [19].

Logistics services suppliers' differentiation is made based on a partner's qualification definition of the separate sector and all different types of aroused situation. At the beginning of the cooperation stage the logistics services supplier is being held as the subcontractors, in an innovative attitude in a process of cooperation they look like "co-authors" and "designers" or "managers" of the delivered network. In the figure 2 the characteristic of the main logistics services basic supplier were presented.

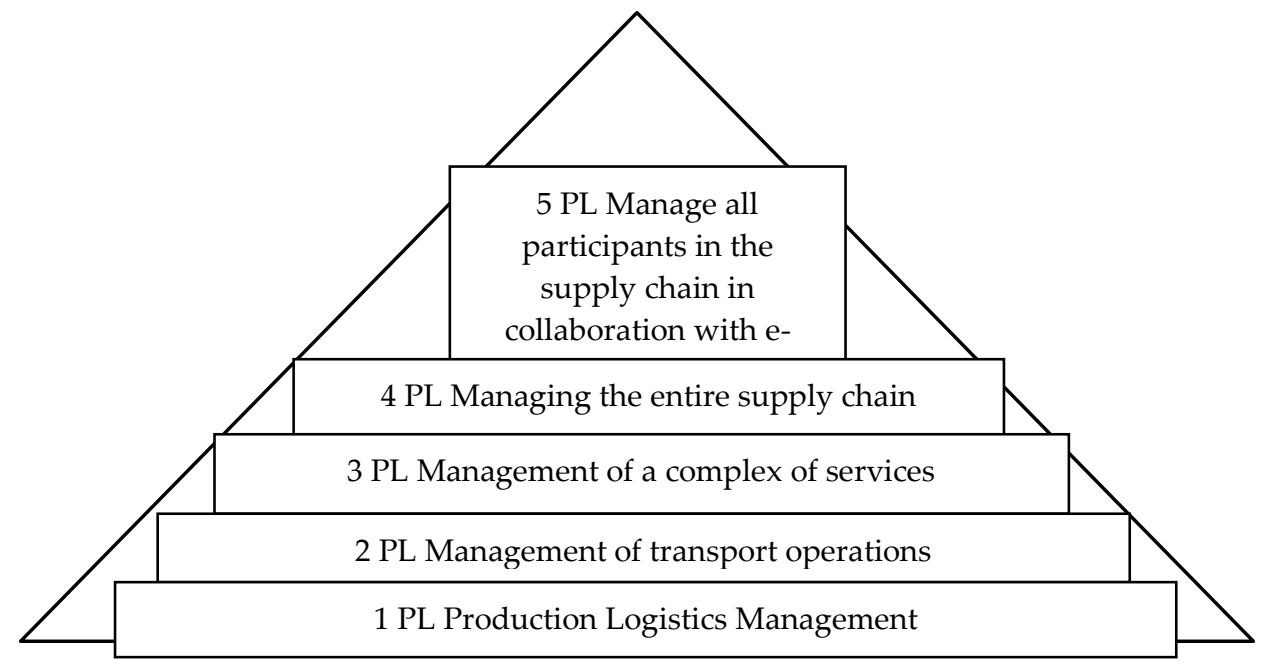

Fig. 2. Logistics services type's supplier characteristics. Source: developed by the authors. 
Having being existing scientific theses analyzed the researches testify that main attention is made toward the Companies consume the logistics services, but not big attention are to be paid to outsourcers are providing these services. Logistics effectiveness and Enterprise effective activities are defined by a term of effective cooperation by all the processes parties.

Foreign trade activity foresees the Enterprise activity out of the native country, which has been accompanied by the risk and uncertainty rising. These are defined for foreign market logistics outsourcing using.

In the case the Enterprise has trade-economic connections with the foreign trade suppliers or has a plan to come out to the foreign markets with own product the necessity has been aroused for looking out to a staff are able to provide the above processes. In case of Enterprise strategic orientation to foreign markets is necessary for own Dpt. establishing with the international specialists in it. But in case, when the necessity of foreign trade activity is aroused only sometimes, to keep working this Dpt. is unjustified expensive. The best way to dissolve this problem is foreign trade outsourcing.

Foreign trade outsourcing has foreseen organizational and technical processes transfer connected with imported goods buying and export sale to aside Company - outsourcer. This method priority is additional recourses release of the Company (financial, labor, timing) which can be directed to production and business. In nature, logistics outsourcing means to authorization specialized aside Company all the type of works connected with foreign trade activity.

Outsourcing advantages by foreign trade activity:

1. A better understanding of the market and consumers market features (tastes and consumers preferences).

2. Expenses shortage for Company establishing, office opening and wages, taxes payments.

3. Wide range receiving of the logistics services.

4. Products sale rising and sale Enterprise foundation as a result.

5. Deduction (nonpayment) of some foreign currency payments, customs procedures.

Logistics servicing providing by foreign trade activity:

- foreign supplier selection and commodity buying;

- paperwork;

- commodity storage organization with a complex of satellite services;

- balance keeps checking in real-time;

- foreseen and readiness for demand growing;

- commodity moving control by WMS online system;

- transportation logistics and commodity insurance by foreign trade operations are to be made by outsourcers;

- foreign contracts preparing and management;

- customer and brokers servicing;

- export and import permission preparing;

- commodity certification;

- most trading effective scheme selection;

- work with regulated bodies;

- foreign currency regulation;

- VAT payments and other types of payment.

Custom clearance needs professional and experienced staff. This complex permits the invention of the best version of delivery organization and custom clearance.

Thus, logistics outsourcing permits the Company to minimize expenses, raise a work effectiveness concern to foreign partner searching, to speed the process up thanks to transportation points solving by the complex. Taking into consideration the validity and difficulty of this point, taking management decision concern outsourcing implementation into enterprise foreign trade activity needs to be carefully weighed and justified. This management decision implementation process is made in the terms of uncertainty. It makes the process more difficult and reduces the effectiveness of the accepted decision 
[20]. Within a need stipulation by logistics outsourcing a model decision making is proposed about logistics outsourcing implementation by foreign trade activity providing (Fig. 3).

According to Figure 2 this decision-making process has to be made in two stages - preparatory and basic. On the preparatory the tasks are to be defined including foreign trade activity development; enterprise expenses optimization thanks to logistics outsourcing implementation, additional outcome receiving, and foreign partners searching. All these tasks can be solved successfully by outsourcing implementation.

On the stage of existing enterprise advantages is necessary to define logistics functions, and activities ranges which can be passed into outsourcing out, besides this concern to transportation logistics, foreign partners searching and custom clearance. These functions transfer can be full (all enterprise logistics functions passing out into outsourcing) or partial (only some functions, for example, transportation logistics).

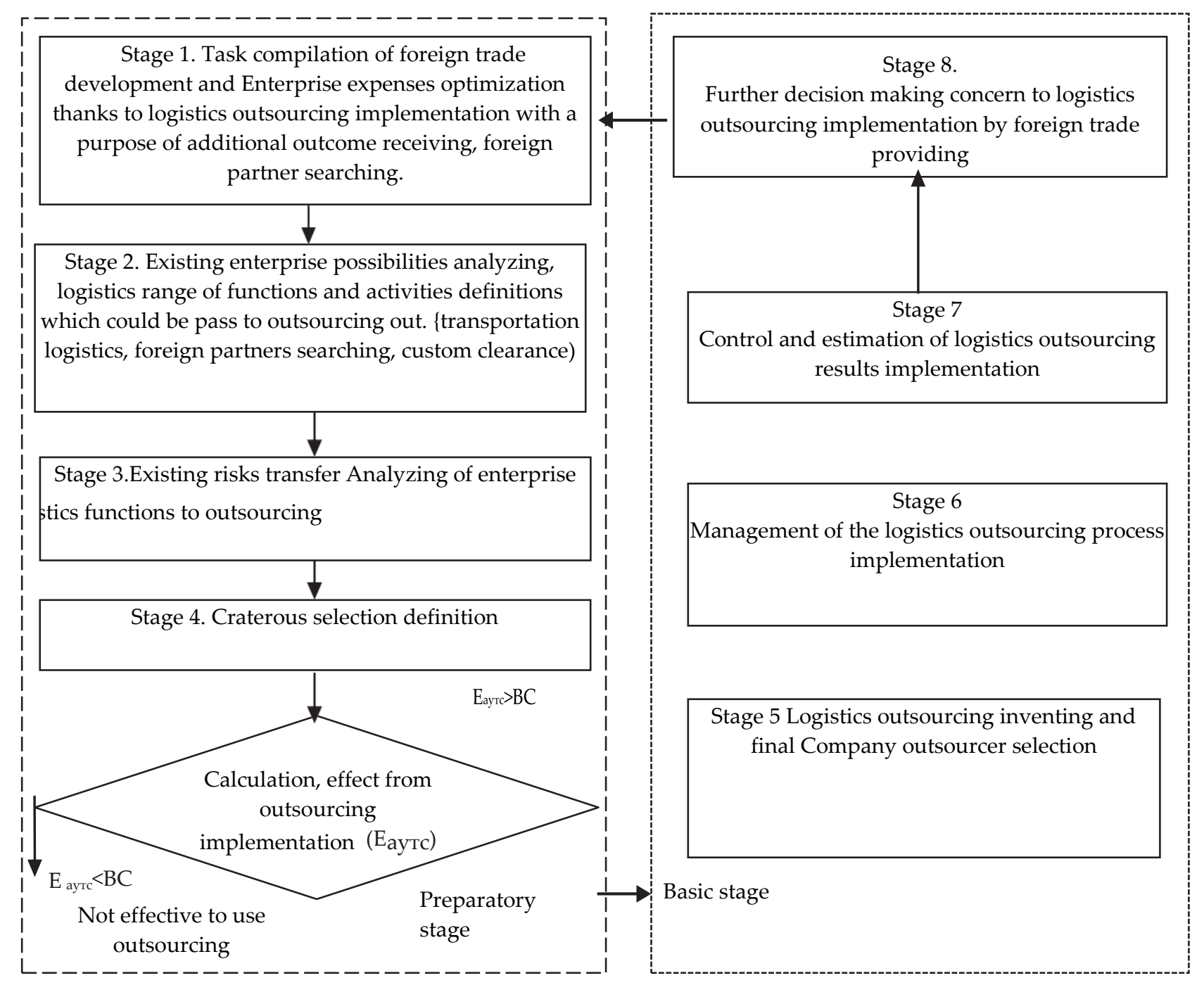

Fig. 3. Management decision making concerns to logistics outsourcing implementation possibility by foreign trade enterprise activity. Source: designed by the authors on the base of [21].

The next stage requires a perfect estimation of possible risks from decision-making concerns to outsourcing using and also from its economic validity. Within these instruments can be used Mc. Kinsey model: "Price watehouse Coopers" methodology, BCG model (proposed by Derting), Khlebnikov outsourcing matrix, Y. Mitrophanov proposed matrix, M. Tatjanok Methodology, Y. Zhelinskyj methodology. 


\begin{tabular}{|c|c|c|}
\hline $\begin{array}{c}\text { Name of } \\
\text { methodology } \\
\text { author }\end{array}$ & Characteristic & $\begin{array}{l}\text { The parameters that the technique takes } \\
\text { into account }\end{array}$ \\
\hline $\begin{array}{l}\text { Mc. Kinsey } \\
\text { model }\end{array}$ & $\begin{array}{l}\text { Outsourcing is to made on the basis of: } \\
\text { 1. Export evaluation of involvement to } \\
\text { technological network for consumer's value } \\
\text { creation. } \\
\text { 2. Profitability of non-profile activities from the } \\
\text { view of the clear expenses and Enterprise outcome } \\
\text { contribution. } \\
\text { Thus, business process separation according to the } \\
\text { reasons: "profitability" and technological process } \\
\text { involvement". } \\
\text { This methodology gives a possibility to reveal non- } \\
\text { profile and unprofitable process and Dpt. }\end{array}$ & $\begin{array}{l}\text { Displays two criteria's: non-profile actives } \\
\text { involvement to technological network } \\
\text { concerns to consumer value creation }\end{array}$ \\
\hline $\begin{array}{l}\text { Price waterhouse } \\
\text { Coopers (20) }\end{array}$ & $\begin{array}{l}\text { Matrix has two factors: active importance and } \\
\text { active strategic importance. Options of these facts } \\
\text { combinations in the matrix give four options of a } \\
\text { solution. Combination of a low strategic } \\
\text { importance and competition actives importance } \\
\text { transfers the Dpt. functions factors to an aside } \\
\text { organization }\end{array}$ & $\begin{array}{l}\text { Analyze had been made based on } \\
\text { comparison parameters - "active } \\
\text { compatible importance" and "strategic } \\
\text { importance of Dpt. for Enterprise and } \\
\text { separates four types of decision making }\end{array}$ \\
\hline $\begin{array}{l}\text { BCG outsourcing } \\
\text { matrix }\end{array}$ & $\begin{array}{l}\text { Permits to provide business processes separation } \\
\text { expediency outsourcing analyzing according to the } \\
\text { following elements - strategic influence; financial } \\
\text { influence, business - influence; business - risks }\end{array}$ & $\begin{array}{l}\text { Analyzing is to be provided based on five } \\
\text { elements: financial elements; strategic } \\
\text { influence; business - influence, business - } \\
\text { risks }\end{array}$ \\
\hline D. Khlebnikova & $\begin{array}{l}\text { Two factors instruments analyzing: the analysis is } \\
\text { to be made by two basic factors: "strategic } \\
\text { importance" and "competencies quality compare } \\
\text { with competitors and market totally" which are } \\
\text { estimated by three levels. } \\
\text { This matrix of outsourcing is a method of object } \\
\text { review separation to } 3 \times 3 \text { matrix segments, by which } \\
\text { can be a separate proceedings Dpt., type of work } \\
\text { toward to a separated specialist, the carrier of a } \\
\text { competence. } \\
\text { This method is to be differenced by estimation } \\
\text { criteria scale. In the case of data separation by the } \\
\text { matrix field the variants are to be produced of } \\
\text { decisions making. }\end{array}$ & $\begin{array}{l}\text { In the two measurements matrix were } \\
\text { given: strategic importance, competencies } \\
\text { quality /works/, the results compare with } \\
\text { existed on the market. } \\
\text { Strategic importance has its own } \\
\text { components: technological involvement } \\
\text { which considers some type of Enterprise } \\
\text { activity: profitability factors; owner } \\
\text { intentions; social - economic and political } \\
\text { aspects of possession. } \\
\text { Outsourcing matrix horizontal scale is - } \\
\text { competencies quality/works/ results } \\
\text { compare with existed on the market. Due } \\
\text { to estimation, the matrix is necessary: } \\
\text { To understand that the Company makes } \\
\text { the goods are buying; } \\
\text { To know which competency confirms the } \\
\text { business and to answer a key question: } \\
\text { why makes it important to analyze real } \\
\text { stuff competencies; } \\
\text { To analyze competitive environment; } \\
\text { On the infrastructure analyzing base to } \\
\text { define market terms; } \\
\text { To give a possibility to make a } \\
\text { transformation }\end{array}$ \\
\hline UBS (21) & $\begin{array}{l}\text { Business functions separation on the decision to } \\
\text { outsourcing is to be made with a decision-making } \\
\text { matrix invented by IBS consulters. } \\
\text { By axis X the matrix is made service value relation } \\
\text { inside of the Enterprise to the value of the same } \\
\text { value on the market; by axis Y - business-functions } \\
\text { quality characteristics compare with the market. By } \\
\text { this result, the matrix is being divided into nine }\end{array}$ & $\begin{array}{l}\text { Outsourcing matter is to be considered by } \\
\text { four important aspects: } \\
\text { Strategic priorities economical } \\
\text { effectiveness; } \\
\text { Services management transferred to } \\
\text { outsourcing; } \\
\text { Reliability and risks }\end{array}$ \\
\hline
\end{tabular}




\begin{tabular}{|c|c|c|}
\hline $\begin{array}{c}\text { Name of } \\
\text { methodology } \\
\text { author }\end{array}$ & Characteristic & $\begin{array}{l}\text { The parameters that the technique takes } \\
\text { into account }\end{array}$ \\
\hline & $\begin{array}{l}\text { segments, each of the segment confirms one from } \\
\text { the fourth conclusions: } \\
\text { Outsourcing implementation } \\
\text { - Refusal from the own Dpt. and buying the same } \\
\text { goods on the market; } \\
\text { - Development - improvement of business } \\
\text { functions for the quality raising services or cost } \\
\text { reducing; } \\
\text { - Development or outsourcing - two decisions are } \\
\text { possible (advantages depend from Enterprise } \\
\text { policy to considered business-functions separation } \\
\text { - business function is compatible and can be } \\
\text { separated in different business for profit receiving. }\end{array}$ & \\
\hline $\begin{array}{l}\text { Zhelinskogo } \\
\text { methodology }\end{array}$ & $\begin{array}{l}\text { Outsourcing effectiveness is the sum of outcome } \\
\text { and expenses in a separate sphere of activity. The } \\
\text { changes could be positive and negative but sum of } \\
\text { the needs is to be more than } 0 \text {. The difference } \\
\text { between total incomes and expenses after } \\
\text { outsourcing implementation needs to be bigger } \\
\text { than the difference in the profits and expenses }\end{array}$ & Enterprise profits and expenses analyzing \\
\hline
\end{tabular}

Tab. 1. Compatible characteristic methodology of evaluation management decision making concerns to logistics outsourcing. Source: formed by the authors.

The methodology method permits to make estimation by the parameters complex. It does not consider the human being factor within transferring of the own Company management functions to the management by aside Enterprise.

The risks (the disadvantages) of logistics outsourcing implementation are to be arisen by the following cases:

- big value of the expenses rising with a connection of a process and the functions to outsourcing;

- big value of expenses are used with the purpose of survival cooperation with the suppliers which supply outsourcing services;

- non foreseen ability of outsourcing Company bankruptcy;

- professional ability improving the another Enterprise than own stuff;

- limitation of logistics outsourcing juridical regulation definition.

By definition of logistics, outsourcing effectiveness is necessary to consider the alternative value that is the possibility of released finance using for another Company activity. It is advisable to use the only partial transfer (some separate logistics functions) to logistics and to raise the activity in the future by a term of effective cooperation. Besides, on all levels of outsourcing implementation in logistics is necessary to use a comprehensive control and results in evaluation of logistics outsourcing implementation.

The most important factor by Enterprise logistics system outsourcing is the effective organization of economic activity.

According to management decision making invented model concerns logistics outsourcing implementation by enterprise activity calculates outsourcing implementation effectiveness. For this, we used Y. Zhelinstskiy methodology [9].

According to this methodology for outsourcing effectiveness evaluation the sum of incomes and expenses needs to be calculated in the enterprise activity spheres after and before outsourcing implementation. As a result, the difference between total incomes and expenses after outsourcing implementation needs to be more from the difference of incomes and expenses before outsourcing implementation.

Formula is to be developed: 
$\mathrm{P}_{1}$ - total incomes before outsourcing implementation;

$\mathrm{V}_{1}$ - total expenses before outsourcing implementation;

$\mathrm{P}_{2}$ - total incomes after outsourcing implementation;

$\mathrm{V}_{2}$ - total expenses after outsourcing implementation.

Logistics outsourcing evaluation of Vega Ltd. provides with a method where changes of Enterprise incomes and expenses are combined.

This methods group confirms to common attitude for result evaluation based on incomes and expenses changes and is very simple for use.

Private Enterprise Vega Ltd. has been established on May 08, 2008. The main activities consist of: wholesale of wheat and animal feeds, vegetable oil for technical purposes and truck service. 20 workers work on this Enterprise.

The Enterprise sales the products as in the internal market and provides foreign trade activity. Export of the commodities has been providing to Lithuania, Estonia, Poland, Czech Republic, Belorussia and Moldova but not exceeding the products sale on the external market because of tough policy and EU quotas. In EU Countries a biodiesel is produced from vegetable oils and from second raw materials such as a press an animal feeds are made which afterward are coming back to Ukraine as a premixes and a protein - vitamin-mineral supplements.

Additionally, the Enterprise gives a service of trucking of liquid, bulk, cargo and assembled cargos to the countries such as: Austria, Germany, Nederland, Greek, Bulgaria, Romania, Czech Republic, Slovakia, Poland, Latvia, Estonia, Moldova, and Belorussia. The oils, juice concentrates, jams, wheat, wood products, parts of furniture, fire wood and the pallets are exported from Ukraine. The mineral fertilizers, metal sheets, animal feeds are imported into Ukraine.

Among the basic negative factors influences Enterprise work are corruption on a custom, Ukrtranssecurity corruption that connected to Poland and Austria issuing permission; credits involvement with a high rate.

The Enterprise has an intention to make transportation logistics outsourcing with a Polish Company which provides dispatching services, minimizes an empties trucks running that influenced on transportation Dpt. within long period of time and expenses caused. In the future this Enterprise plans to pass goods sales out to a foreign market for outsourcing.

Due to understand a reason and main of transfer some function by Vega Ltd. to outsourcing let's see the following example:

A truck (type DAF and truck tanker) makes move for a route - Chortkiv (Ukraine) - Orkhly (Moldova) - Voljkersdorf (Austria). From Moldova to Austria a juice concentrate is transported.

To calculate an expenses: $24 \mathrm{mt}$. $\times 110$ euro $(1 \mathrm{mt}$. transportation cost) $=2640 \mathrm{hrn}$. x 26,9 (euro exchange rate)

1. Fuel - $1000 \mathrm{~km} \times 0,38$ (consuming with cargo) x 26,9 (exchange rate) = $10222 \mathrm{hrn}$.

2. Insurance (green card) $=2000 \mathrm{hrn}$.

3. Permits:

- Moldova (1 pcs.) $=500$ hrn .

- Transit via Moldova through Ukraine $=2690 \mathrm{hrn}$.

- Poland $(1$ pcs. $)=190$ hrn.

- Czech Republic (1 pcs.) $=170$ hrn.

- Austria (2 pcs. - entrance/exit) $=610$ hrn.

4. Payment a truck transit with ecological secure class not lower than Euro 5.

- Moldova - 0 hrn;

- Poland $-880 \mathrm{~km} \times 0,27 \mathrm{zl} .=338 \mathrm{zl}$. 6,357 (exchange rate) $=1513 \mathrm{hrn}$.

- Czech Republic 340 km. x 3 cor. $=1020$ cor. X 1,07 (exchange rate) $=1091$ hrn.

- Ausria $202 \mathrm{~km}$. x 0,4 euro $=81 \times 26,9$ (exchange rate) $=2179 \mathrm{hrn}$.

5 . Driver wage $-71016 \times 0,14$ (percentage wage) $=9942 \mathrm{hrn}$.

6. Taxi driving $-1000 \mathrm{~km}$. x 0,22 (fuel consuming without cargo) x 26,9 (exchange rate).

7. Truck amortization for one route $-4810 \mathrm{hrn}$. 
8. Bookkeeping, director's wages, 2 mechanics wage, office manager wage with taxes $-750 \mathrm{hrn}$. per one route.

Total expenses for the route are $42588 \mathrm{hrn}$. Before Enterprise was planning to transfer logistics to outsourcing the truck had been returning to Ukraine without cargo that was making the profit lower and caused the losses sometimes.

Thus, calculate an outcome before transferring logistics to outsourcing:

$71016-42585=28431 \mathrm{hrn}$. cleaned profit.

The trucks are coming back with the other loads after faced with outsourcing. Let's look at the sample: the truck is backed from Austria and The Czech Republic was loaded by glycerol $24 \mathrm{mt}$ x 95 euro/mt $\times 26,9$ (exchange rate) $=61332 \mathrm{hrn}$.

A route Volkerscdorf (Austria) - Znajmo (Czech Republic) - Dybno (Ukraine).

Expenses calculation:

1. Tank cleaning - 140 euro $\times 26,9$ (exchange rate) $-3766 \mathrm{hrn}$

2. Expenses for the route Volkerscdorf (Austria) - Znajmo (Czech Republic) $=170 \times 0,22$ (fuel consuming for $100 \mathrm{~km}$ without cargo) x 26,9 (exchange rate) $=1006 \mathrm{hrn}$.

3. Expenses for the rout Znajmo (Czech Republic) - Dybno (Ukraine):

$905 \mathrm{~km} \times 0,38$ (fuel consuming for $100 \mathrm{~km}$ with cargo) $\times 26,9$ (exchange rate) $=9251 \mathrm{hrn}$.

4. Custom duty for entrance to Ukraine $-620 \mathrm{hrn}$.

5. Driver wage $-8300 \mathrm{hrn}$.

6. Tank cleaning $2-1600 \mathrm{hrn}$.

7. One route track amortization $4810 \mathrm{hrn}$.

8. The wages of bookkeeper, director, two locksmith office manager, mechanic with the taxes -750 hrn. per one route.

9. According of the logistics outsourcing Contract N1608/18 dd.01.08.18. outsourcer receives 10\% of profit from the cargo founded by him without expenses connected to truck taxi to a place of loading.

Thus outsources profit is 61332 - 1006 (gas consuming for the rout Volkerscdorf (Austria) - Znajmo (Czech Republic) - 60326 x 10\% - 6033 hrn.

Gross expenses for this route are $30576 \mathrm{hrn}$.

Cleaned profit for this route is $28431+30756=59181 \mathrm{hrn}$.

$\mathrm{E}=59187-28431=30756 \mathrm{hrn}$.

From above mentioned - the profit is growing after logistics transferring to outsourcing. It means for Vega Ltd. outsourcing is profitable.

Let's make a forecast for Vega Ltd. to 2020 with two variants of development - without transportation logistics transfer to outsourcing (variant 1) and in case of outsourcing Contract implementation to Enterprise transportation logistics (variant 2).

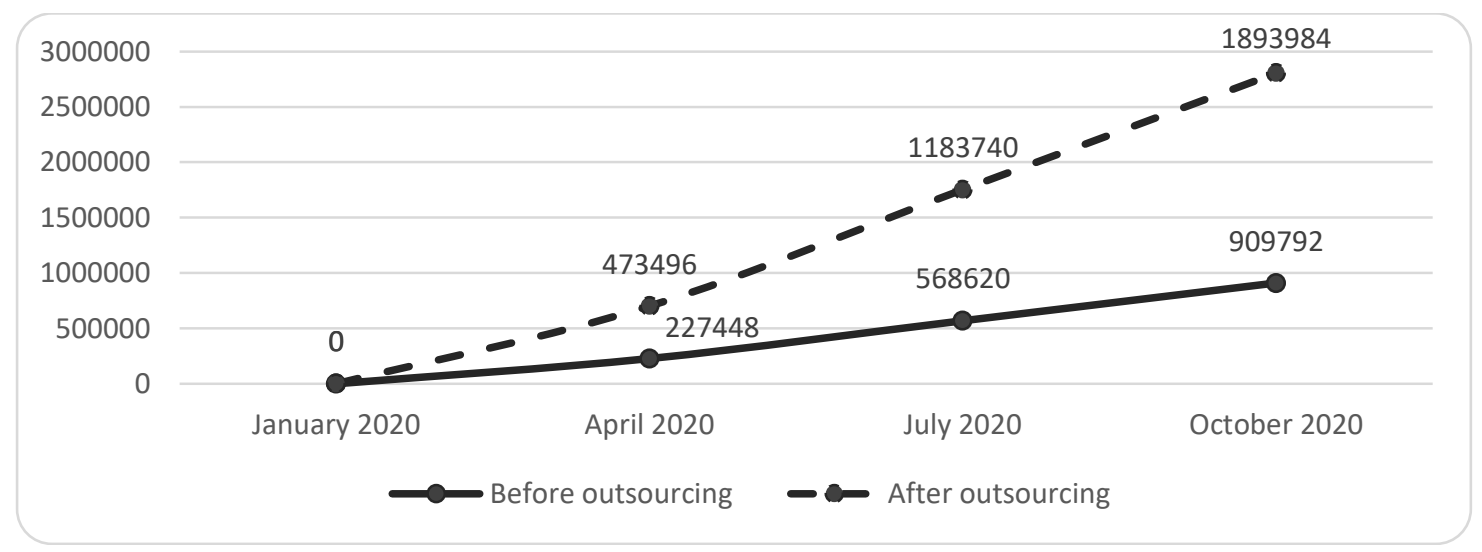

Fig. 4. Profit rising forecast to 2020 without outsourcing and by the logistics transfer to outsourcing, hrn. Source: formed by the authors. 
The truck for one month makes 4 routs. Per one year the truck works 9 months. For this period the truck makes $4 \times 9=36$ routs.

In the case for one route the profit is 59187 than one truck for 36 routs makes $59187 \times 36=2130732$ hrn.

Enterprise transportation logistics effectiveness calculation is submitted in a table 2 with a possibility of any type of development.

\begin{tabular}{|l|l|l|}
\hline Data & Variant 1 & Variant 2 \\
\hline Expenses (1 rout) & 42585 & 30756 \\
Cleaned profit (1 rout) & 26431 & 59187 \\
Cleaned profit (a gear) & 1023516 & 2130732 \\
\hline
\end{tabular}

Tab. 2. Two variants of the Enterprise logistics activity data, hrn. Source: formed by the authors.

In winter months with the weather matters, the truck will not be involved for any of the services. The first working month would be - a march. For March and April the truck make routs. Thus, (picture 4):

variant 1 - the Enterprise would get a profit $-26431 \times 8=227448 \mathrm{hrn}$.

variant 2 - the Enterprise would makes a profit $59187 \times 8=473496 \mathrm{hrn}$.

In the same way Enterprise approximate profit to another months: up to July and October.

July:

- variant $126431 \times 20=568620 \mathrm{hrn}$.

- variant 2591187 × $20=1183740 \mathrm{hrn}$.

October:

- variant $1-28431 \times 32=909792 \mathrm{hrn}$.

- variant $2-591187$ x $32=1893964 \mathrm{hrn}$.

So, outsourcing is profitable for Vega Ltd. That is why it is a reason to outsources services using not only concern to transportation logistics but for another enterprise activity.

\section{CONCLUSIONS}

During the research of logistics outsourcing and its influences on foreign trade Enterprise activity the following conclusions were made:

1. In logistics activity, the outsourcing is a modern business - model. This implementation attitude gives a possibility to get the utmost competitive advantages in Enterprise activity. Basic motives caused for logistics functions transfer to outsourcing are: to make business more manageable; to reduce the transaction costs and within this to obtain a profit.

2. Due to define a necessary of second functions transfer to outsourcing is necessary to take into account all positives and negatives sides of this activity.

By the outsourcing process development, the positive and negative factors have been operating as well. But there is a matter that the most important limitation has to be an economic profit and its use. Because there are many cases when to transfer to external management other functions is not reasonable.

Possibility for the Enterprise - Customer to concentrate the trade activity by the own forces within basic directions of business is most advantage of outsourcing, that is only why the Enterprises second functions transfer to other specialized Companies lowering the servicing expenses of business-project; provision of favorable conditions and world class of services, outcome rising, foreign currencies welcoming.

3. For modern Enterprises problem is actual logistics outsourcing implementation. The calculations were made concern to research Enterprise logistics transportation outsourcing effective using present the advantages of these steps. 
The foreseen for 2020 year with two tips calculation (with using of outsourcing and without) indicates for the bigger opportunity for profit dynamic of the Enterprise.

4. Thus, a transition to logistics outsourcing - is a strategy that is directed for profit and competitiveness rising by long term period. During outsourcing implementation in Enterprise logistics the Enterprise received a possibility to concentrate the resources within profiled business and do not be involved in establishing and supporting of an infrastructure unconnected with it.

5. At present, within a transfer of logistics business - process to outsourcing analyze is necessary for each of the cases. The outsourcers - enterprises expenses present a necessity to account the number of terms and factors with a matter to make an outsourcing project successful for the Customer and Outsource - Company.

The concrete analyses help to clarify in which directions outsourcing implementation are more effective and resources saving with outsourcing help give a possibility not only to survive in the crisis conditions but to get a success.

Using of the considered and improved models and attitudes will help to raise a relevant management decisions anyway, but hardly make the process of decision making easier.

\section{REFERENCES}

[1] Bagchi P., Virum H. European logistics alliances: a management model. International Journal of Logistics Management, 7 (1) (1996), 93-108.

[2] Sahay B.S., Mohan R. 3PL practices: an Indian perspective. International Journal of Physical Distribution $\mathcal{E}$ Logistics Management, 36 (9) (2006), 666-689. doi: 10.1108/09600030610710845

[3] Percentage of 3PL users who outsource logistics services as of 2018, ranked by the most frequently outsourced services. Available at: https://www.statista.com/statistics/660142/transportation-andlogistics-mostoutsourced-services/

[4] Krasnoshapka V.V., Trohumets I.I. Outsourcing and its application in enterprises of Ukraine. Efektyvna ekonomika, 5 (2015). Available at: http://www.economy.nayka.com.ua/?op=1\&z=4097. (in Ukrainian)

[5] Tryfonova O.V., Trushkina N.V. State of Ukrainian transport logistics, its problems, and development tendencies. Herald of the Economic Sciences of Ukraine, 1 (2019), 143-149. Available at: http://nbuv.gov.ua/UJRN/Venu_2019_1_25. (in Ukrainian)

[6] Glushenko T.M. Analysis of logistics services in modern world market. Scientific Herald of Kherson State University, 6 (1) (2014), 169-171. Available at: http://nbuv.gov.ua/UJRN/Nvkhdu_en_2014 _6\%281\%29_42 (in Ukrainian)

[7] Zavgorodniy K.V. Development of logistics outsourcing as a tool for managing regional transformations. Scientific Herald of Kherson State University, 21 (2016), 96-99. (in Ukrainian)

[8] Pasichnyk A.M., Lebid I.H., Kutyriev V.V., Buherko K.M. Problems and prospects of development of a logistic outsourcing in transport system of Ukraine. Upravlinnia proektamy, systemnyi analiz i lohistyka. Seriia "Tekhnichni nauky", 14 (1) (2014). Available at: https://docplayer.net/ 38988615-Problemi-taperspektivi-rozvitku-logistichnogo -autsorsingu-v-transportniy-sistemi-ukrayini.html (in Ukrainian)

[9] Bilovskyi K.E. Status and prospects of development of the logistics services market in Ukraine. Herald of Khmelnytskyi national university. Economic sciences, 4 (2) (2016), 25-29. (in Ukrainian)

[10] Hrytsyna L.A., Koshivska M.V. Current state and development prospects of transport logistics in Ukraine. Market Infrastructure, 18 (2018), 11-18. Available at: http://www.marketinfr.od.ua/journals/2018/18_2018_ukr/5.pdf (in Ukrainian)

[11] Hryniv L.V., Sinicia S.M. Ways to increase the competitiveness of international transport. Khmelnitsky National University scientific-theoretical journal. Science and economics, 19 (2010), 115-121. (in Ukrainian)

[12] Mykhailiv H.V., Voloshchuk I.A., Oleksyuk V.M. Mechanisms of formation and peculiarities of development of logistic infrastructure of the region. Bulletin of the Carpathian University. Economy series, 12 (2017), 29-36. (in Ukrainian) 
[13] Economic statistics / Economic activity / Transport. Available at: http://ukrstat.gov.ua/operativ/ menu/menu_u/tr.htm (in Ukrainian)

[14] List of Companies - Third Party Services in Logistics Management (3PL) - Ukraine. Available at: https://ua.kompass.com/a/услуги-третьеи-стороны-в-управлении-логистикои-3pl/7594025/ ） (in Russian)

[15] Sustainable Logistics Strategy and Action Plan for Ukraine. A project for consideration. Available at: https://mtu.gov.ua/files/Logistics.pdf (in Ukrainian)

[16] Outsourcing as a tool for service logistics. Available at: https://studme.com.ua/1595021014291/logistika/ autsorsing_kak_instrument_servisnoy_logistiki.htm (in Ukrainian)13

[17] Logistics as a tool for optimizing business processes and the direction of scientific knowledge. Available at: https://pidru4niki.com/71570/logistika/logistika_instrument_optimizatsiyi_biznesprotsesiv_napryam_naukovogo_piznannya (in Ukrainian) 15

[18] Dovba M.O. Outsourcing in the market of logistics services: prospects in Ukraine. (in Ukrainian)21

[19] Liginenko L.O., Frolova Yu.Yu. Outsourcing as a tool to optimize and improve business performance. Vtntdzhment, Kyiv, 2005. (in Ukrainian)

[20] Hryniv L.V., Vachil O.P. Methods for evaluating the effectiveness of managerial decision making in uncertainty. Bulletin of the Carpathian University. Economy series, 11 (2015), 292-296. Available at: http://nbuv.gov.ua/UJRN/Vpu_Ekon_2015_11_58. (in Ukrainian)

[21] Logistics outsourcing. Available at: https://tsl.kname.edu.ua/index.php/en/8-glavnaya/26-logisticoutsourcing (in Ukrainian)

[22] 2019 third-party logistics study: The State of Logistics Outsourcing. Available at: https://www.supplychain247.com/paper/2019_third_party_logistics_study_the_state_of_logistics_outso urcing

[23] Zaloznova Yu.S., Trushkina N.V., Kocheshkova I.M. System approach to risk management of logistic activity of enterprises. Herald of Khmelnytskyi national university, 3 (2) (2018), 50-53. Available at: http://nbuv.gov.ua/UJRN/Vchnu_ekon_2018_3\%282\%29_11 (in Ukrainian)

[24] Catalog of enterprises of Ukraine. Available at: https://yellow.com.ua/rList.aspx?r=1008 (in Russian)

[25] Langley J. Third-Party Logistics Study, 2018. Available at: https://mymaritimeblog.files.wordpress.com /2017/10/3pl_2018_study.pdf

Address: Oleg Tkach, Liubov Hryniv, Halyna Mykhailiv, Vasyl Stefanyk Precarpathian National University, 57 Shevchenko St., Ivano-Frankivsk, 76018 Ukraine.

E-mail: oleg.tkach@pnu.edu.ua, liubov.hryniv@pnu.edu.ua, halyna.mykhailiv@pnu.edu.ua

Received: October 30, 2020; revised: November 12, 2020.

Ткач Олег, Гринів Любов, Михайлів Галина. Логістичний аутсорсинг як ефективний механізм діяльності підприемства. Журнал Прикарпатського університету імені Василя Стефаника, 7 (3) (2020), 97-114.

Метою статті $є$ обгрунтування логістичного аутсорсингу як ефективного механізму підвищення ефективності діяльності підприемства.

Автори узагальнюють аргументи та контраргументи в науковій дискусії щодо иогістичного аутсорсингу як одного з найкращих методів оптимізації ресурсів у діядьності підприемств, одного 3 важливих факторів сучасного бізнесу. Систематизація результатів дослідження наукових джерел дозволила виявити проблеми використання аутсорсингу в різних сферах діяльності суб'єктів господарювання. Систематизація досліджень аспектів управління підприємством на основі логістичних підходів дозволила сформулювати твердження про те, що особливе значення у всьому світі в иогістиці приділяється аутсорсингу. Протягом багатьох років у цій галузі спостерігається 
тенденція до передачі частини або всіх функцій догістики спеціалізованим компаніям, і аутсорсинг логістичних послуг використовується переважною більшістю підприємств. Оскільки, із вищим рівнем споживання в країні, виникає більша необхідність залучати до ланцюга поставок товари кваліфікованих иогістичних операторів та переводити частину їх операцій на догістичний аутсорсинг.

Автори оцінюють иогістичний аутсорсинг підприємства ПП "ВЕГА $Л Т Д$ з за методом Желінського Ю.А., який поєднуе зміну доходів і витрат підприємства. На підставі розрахунків доведено, що аутсорсинг для ПП “ВЕГА ЛТД" є економічно доціяьнішим. Тому ефективно використовувати підрядні послуги не лише для транспортної иогістики, а й для іншої логістичної діядьності підприємства.

У процесі дослідження проблем догістичного аутсорсингу та його впдиву на ефективність зовнішньоекономічної діяльності компанії автори довели, що аутсорсинг у логістиці є однією 3 найсучасніших бізнес-моделей. Використання цього підходу дає змогу досягти значних конкурентних переваг у діядьності підприємства. Основними мотивами, що обумовлюють аутсорсинг догістичних функцій, є: бажання зробити бізнес керованим, зменшити трансакційні витрати при одночасному отриманні якісного обслуговування та прибутку. Результати дослідження мають практичне значення і можуть бути корисними науковцям, зацікавленим у вивченні иогістичного аутсорсингу, а також підприємствам, де аутсорсинг використовується найчастіше.

Кдючові слова: догістичний аутсорсинг, види аутсорсингу в догістиці, постачальники логістики, оператори, форми співпраці підприємств, иогістичні послуги. 